\title{
Sedentary Lifestyle as a Risk Factor for Obesity in Stunted Adolescents at SMPN 1 and 2 Pasar Kemis, Tangerang
}

\author{
Ayatun Fil IImi ${ }^{*}{ }^{*}$ Diah Dwi Pujiastati ${ }^{1}$ \\ ${ }^{1}$ Programme of Study in Public Health, STIKes Kharisma Persada, Pamulang, Tangerang Selatan, Indonesia
}

\section{A R T I C LE I N F O}

\section{IAKMI IPHJI use only:}

Received date : 31 March 2020

Revised date : 19 April 2020

Accepted date : 22 May 2020

\section{Keywords:}

stunted

obesity

sedentary lifestyle

adolescents

\begin{abstract}
A B S T R A C T
Short stunted stature is a condition where z-score for height per age is less than -2 SD. Stunted children have a risk of 3,4 times being obese adolescents. In stunted adolescents, there is a disruption of the fat oxidation process that can cause obesity. In addition, stunted adolescents are less active than non-stunted. The purpose of this study was to determine whether a sedentary lifestyle is a factor that increases the risk of obesity in stunted adolescents. This study is an analytical study with a cross sectional research design. The participants are 63 adolescent selected by purposive sampling. Measurement include z-score height per age and BMI per age. Sedentary lifestyle is determined using modified Adolescent Sedentary Activity Questionnaire (ASAQ) and it categorize high if $\geq 5$ hours per day. Data was analyzed by Chi-square. Proportion of stunted obesity in SMPN 1 and 2 Pasar Kemis in Tangerang Distric is 44.4\%. There was significant relationship between sedentary lifestyle and obesity in stunted adolescent $(p=0,001)$. Sedentary lifestyle are factors that increase the risk of stunted obesity in adolescents of SMPN 1 and 2 Pasar Kemis in Tangerang Distric. From the results of this study, it is hoped that institutions will continue to provide guidance and outreach to students so that obesity does not occur stunted.
\end{abstract}

(c) 2020 IAKMI Indonesian Public Health Journal. All rights reserved

\section{INTRODUCTION}

Stunted is growth failure caused by chronic undernutrition or infection disease. Stunted was defined by anthropometry height by age below -2 standard deviations (SD) WHO standard. Proven with small height body posture. An estimated 178 million children in the world are too short based on age compared to the growth of WHO (World Health Orgaization) standards [1, 2].

The prevalence of stunted adolescent (age $13-15$ years old) in Indonesia is $25,4 \%$ and in Banten Province is $24.4 \%$ according to Riskesdas 2018 whereas target of RPJMN 20202014 is decreasing prevalence of stunting into $19 \%[3,4]$. It showed that stunted in Indonesia

\footnotetext{
* Corresponding author.

E-mail address: ayatunilmi@gmail.com
}

is high. Previous research in SMPN 1 dan 2 Pasar Kemis showed 35\% student had z-score height-by age below -2 SD.

Previous research explained stunted adult might have impaired fat oxidation. According to Barker hypothesis, growth failure is relevant to lack of internal organ tissue, quality and cell amount such as endocrine disruption. Endocrine disruption affects process of lipid oxidation [5]. Stunted low rate lipid oxidation, especially when fasting and 30 minutes after food consumption. Low-rate lipid oxidation will increasing fat body. High fat intake affect fat deposition formed rapidly [6]. Hence, stunted adolescent tend to have obesity at high risk. Recent researched in Indonesia show that stunted children had 3, 4 times risk long-term effects on nutritional status (obese in adulthood outcome) [7]. 
Stunted adolescents who are obese were defined by z-score BMI-per age >2SD and height-per age <-2SD [8]. Factors traditional lifestyle to sedentary lifestyle, sedentary lifestyle is life pattern with low activities and consumes high intake calorie with low nutritious foods $[9,10]$. They caused energy imbalances of intake and output.

Sedentary lifestyle tend to grow rapidly in society. Previous researched showed that the older age adolescents the lower physic activities. There is growing evidence about adolescents 15 years old spend most of their time with sedentary lifestyle (go to school with motorcycle, lack of activities/plays outside with friends, stay at home playing computer or video games, and watch tv) [11]. Sedentary lifestyle predicted as one caused of obesity factors in stunted adolescents, effect of impaired lipids oxidation and low resting energy expenditure [12].

Based on the introduction, researcher interested to research relationship between sedentary lifestyle and obesity in stunted adolescent at SMPN 1 and 2 Pasar Kemis, Tangerang.

\section{METHOD}

The study was an analytical observation with cross-sectional method. Subjects were 63 students SMP 1 and 2 Pasar Kemis Tangerang with purposive sampling. Inclusion criteria were stunted adolescent with z-score height-per age $<-2$ sd and obesity with z-score BMI-per age $>$ 2sd. Exclusion criteria were adolescent stunted who were consuming drugs for weight gain and grow taller.

The instrument for this study was Adolescent Sedentary Activities Questionnaire (ASAQ) to examine duration of sedentary activities [13]. ASAQ had 11 category of sedentary activities such as watch TV, watch video/DVD, played games in computer, did homework in computer, did tasks without computer, read, had course, walked around, did hobbies, had conversations, and play music instrumental. ASAQ had reliability value 0.57 0.86 , good validity and could identify 3 dimension of sedentary behavioral (type, duration, frequency).

The Analysis was using univariate analysis to described stunted obesity and sedentary lifestyle. The data were using bivariate analysis with chi square test to investigate of the relationship between sedentary lifestyle with stunted obesity in adolescents.

\section{RESULTS AND DISCUSSION}

The proportion of stunted adolescents who are obese is 44.4 percent. Stunted adolescents in the study were measured by comparison of height and age. Obesity is measured using a comparison of BMI with age. Sedentary lifestyle in this study was measured using ASAQ instruments with categories low ( $<5$ hours per day) and high ( $\geq 5$ hours per day). Table 1 shows that the majority of respondents had low sedentary lifestyle characteristics, which amounted to 50.8 percent.

Table 1. Distribution of Characteristics of Research Subjects

\begin{tabular}{lcc}
\hline Charateristics & $\mathrm{f}$ & $\%$ \\
\hline Stunted Adolescent & & \\
Obesity & 28 & 44.4 \\
Non Obesity & 35 & 55.6 \\
Sedentary Lifestyle & & \\
High & 31 & 49.2 \\
Low & 32 & 50.8 \\
\hline
\end{tabular}

Based on table 2 shows that there is a relationship between sedentary lifestyle and obesity in stunted adolescents $(p=0,001)$. The proportion of stunted obesity was more in the high sedentary lifestyle group (33.3\%) compared to the low sedentary lifestyle group $(11.1 \%)$. Odd ratio value in this study is 7,500 . This means that stunted adolescents who have sedentary lifestyle $\geq 5$ hours per day risk 7.5 times becoming obese.

The results of this study are in accordance with the opinions of Amini [2] and Fuadianti [14], that sedentary lifestyle has a positive relationship with obesity. This is because sedentary lifestyle is one of the triggers for obesity. Sedentary lifestyle is expected to further encourage obesity in stunted adolescents, due to impaired fat oxidation and low basal energy calculations (Resting Energy Expenditure). But the result was not in line with Yulia, et al who found that there was no significant difference between total sedentary time between group on school days ( $p>0.05)$, 
Ayatun Fil Ilmi, Diah Dwi Pujiastuti: An Impact of Simulated Interprofessional Workshop on Healthcare Professionals' and Patients'

but there was a considerable difference between the proportion of sedentary time in a day $(p<0.05)$. The porpotion of the sedentary activity-time in day in children with nutritional status was lower than the overweight children [15].

Tabel 2. Results of the Analysis of the Relationship between Sedentary Lifestyle and Obesity in Stunted Adolescents

\begin{tabular}{|c|c|c|c|c|c|c|c|c|c|}
\hline \multirow{3}{*}{ Sedentary Lifestyle } & \multicolumn{4}{|c|}{ Stunted Adolescent } & \multirow{2}{*}{\multicolumn{2}{|c|}{ Total }} & \multirow{3}{*}{ OR } & \multirow{3}{*}{$p$-value } & \multirow{3}{*}{ CI (95\%) } \\
\hline & \multicolumn{2}{|c|}{ Obesity } & \multicolumn{2}{|c|}{ Non Obesity } & & & & & \\
\hline & $\mathrm{n}$ & $\%$ & $\mathrm{n}$ & $\%$ & $\mathrm{n}$ & $\%$ & & & \\
\hline High & 21 & 33.3 & 10 & 15.9 & 31 & 49.2 & & & \\
\hline $\begin{array}{l}\text { Low } \\
(<5 \text { hours/day) }\end{array}$ & 7 & 11.1 & 25 & 39.7 & 32 & 50.8 & 7.500 & $0.001 *$ & $\begin{array}{l}2.431^{-} \\
23.142\end{array}$ \\
\hline
\end{tabular}

*significant at $\mathrm{p}<0.05$

The high sedentary lifestyle in adolescents can be caused by the existence of various means and facilities of technological advances, one of which is social media, causing adolescent to be lazy to move [16]. The use of social media is an activity that makes adolescent have to sit settled for a long time. The use of social media for a long time, will cause someone to be lazy to move so that the use of energy becomes low [17].

Stunted adolescents with sedentary lifestyle $\geq 5$ hours per day have a 7.5 times greater risk of becoming obese compared to $<5$ hours per day. Sedentary lifestyle is one of the mild physical activities. Physical activity affects only one third of a person's energy expenditure of normal weight, but for people who are overweight physical activity has a very important role. At the time of exercise calories will burn, then with a lot of exercise more calories will be lost for the body's metabolism and energy expenditure. Calories indirectly affect the basal metabolic system. People who sit all day will experience decreased basal metabolic system. Lack of movement activity will cause a great cycle, obesity makes sports activities very difficult and cannot be enjoyed and the lack of exercise will directly affect the decline in the person's basal metabolic system [18]. So adolescents stunted with sedentary lifestyle $\geq 5$ hours per day at 7.5 times the risk of becoming obese due to a decrease in the basal metabolic system in the body and consequently a buildup of fat. If this happens continuously it will cause obesity.

\section{CONCLUSION}

From the results of the study it can be concluded that the proportion of stunted adolescents who are obese is equal to 44.4 percent. There was a significant relationship between sedentary lifestyle and the incidence of obesity in stunted adolescents $(p=0.001)$ and CI $(2,431-23,142)$. Stunted adolescents who have sedentary lifestyle $\geq 5$ hours per day have a 7.5 times risk of becoming obese compared to sedentary lifestyle $<5$ hours per day.

\section{ACKNOWLEDGMENT}

I would like to thank the student of SMPN 1 and 2 Pasar Kemis Tangerang who participated in this study for their willingness to give their time to complete the questionnaire.

\section{REFERENCES}

[1] World Health Organization. Nutrition Landscape Information System: Country Profile Indicators. Geneva Switzerland : World Health Organization; 2010

[2] Amini, AZ. Sedentary Lifestyle Sebagai Faktor Risiko Obesitas pada Remaja SMP Stunting Usia 12-15 Tahun di Kota Semarang. Artikel Penelitian Program Studi Ilmu Gizi, Fakultas Kedokteran, Universitas Diponegoro; 2016

[3] Riskesdas. Laporan Nasional Riskesdas 2018. Kementerian Kesehatan RI, Badan Penelitian dan Pengembangan Kesehatan; 2018

[4] RPJMN. Rencana Pembangunan Jangka Menengah Nasional 2020-2024 Indonesia Berpenghasilan Menengah-Tinggi yang Sejahtera, Adil, dan Berkesinambungan. Kementerian PPN/Bappenas; 2018 
[5] Barker, David JP. The Thrifty Phenotype Hypothesis. British Medical Buletin 60: 520. 2001

[6] Hoffman DJ, Sawaya AL, Verreschi I, Tucker KL, Roberts SB. Why are Nutritionally Stunted Children at Increased Risk of Obesity? Studies of Metabolic Rate and Fat Oxidation in Shanytown Children. The American Journal of Clinical Nutrition 72: 702-707. 2007.

[7] Simbolon D. Model Prediksi Indeks Massa Tubuh Remaja Berdasarkan Riwayat Lahir dan Status Gizi Anak. Jurnal Kesehatan Masyarakat Nasional 8(1) : 19-27. 2013

[8] Pacifico L, Anania C, Martino F, Poggiogalle $E$, Chiarelli $F$, Arca $M$ et al. Management of Metabolic Syndrome in Children and Adolescent. Nutrition Metabolism and Cardiovascular Disease 21 : 455-466. 2011.

[9] Mahan LK, Escott-Stump S. Krause's Food Nutrition Therapy. 12th ed. Elsevier : Canada; 2008.

[10] Proverawati. Obesitas dan Gangguan Perilaku Makan pada Remaja. Yogyakarta : Nuha Medika; 2010

[11] Mandriyarini $R$, Sulchan M, Nissa C. Sedentary Lifestyle sebagai Faktor Risiko Kejadian Obesitas pada Remaja SMA Stunted di Kota Semarang. Journal of Nutritionn College, 6(2): 149-155. 2017

[12] Al-Nakeeb $Y$, Lyons $M$, Collins $P$, Al-Nuaim $A$, Al-Hazzaa $H$, Duncan $M J$, et al.
Obesity, physical activity and sedentary behavior amongst British and Saudi yout : $A$ cross-cultural study. International Journal of Environ Res Publich Health, 9(4):1490-506. 2012

[13] Hardy, LL., Booth, ML., Okely, AD. The Realibility of The Adolescent Seentary Activity Questionnaire (ASAQ). Preventive Medicine, 45 : 71-74. 2007

[14] Fuadianti, TF. Hubungan Antara Gaya Hidup Sedentary dan Stres dengan Obesitas pada Ibu Rumah Tangga. Skripsi Program Studi Psikologi, Fakultas Psikologi, Universitas Muhammadiyah Surakarta; 2018

[15] Yulia, C., Khomsan A., Sukandar, D., Riyadi H. Nutritional Status, Physical Activity, and Sedentary Activity of School Children in Urban area, West Java, Indonesia. Jornal Gizi Pangan, 13(3) : 123-130. 2018

[16] Salbe, A. D. Relation Between Physical Activit and Obesity. American Journal of Clinical Nutrition, 78(1): 193-194. 2003

[17] Setiawati, FS., Mahmudiono, T., Ramadhani, N., Hidayati, KF. Intensitas Penggunaan Media Sosial, Kebiasaan Olahraga, dan Obesitas pada Remaja Di SMA Negeri 6 Surabaya Tahun 2019. Jurnal Amerta Nutr 3(3) : 142-148. 2019

[18] Cahyono, JB. Gaya Hidup dan Penyakit Modern. Yogyakarta : Kanisius. 2012 